\title{
Teaching Philosophy of Science to Science Students: An Alternative Approach
}

\section{Ragnar Fjelland ${ }^{1}$}

Accepted: 1 October 2021 / Published online: 24 October 2021

(C) The Author(s) 2021

\begin{abstract}
Although most scientists and their students probably are skeptical towards philosophy, there has been an increasing demand for philosophy, among others philosophy of science, in science education programs. However, for this endeavour to be successful, some obstacles must be overcome. One obstacle is scientists' skepticism towards philosophy. Another obstacle is that the traditional philosophy of science curriculum is not relevant. It was not relevant in the past, and it is even less relevant in the present situation. This paper presents an approach to teaching philosophy of science to science students that is different from traditional approaches. It is based on the assumption that modern science has been dominated by a scientific ideal where measurements and mathematics play a key role. Although this has by and large been a success story, it is imperative that students learn how to apply measurements and mathematics adequately, and to know the limits of their competence. This is particularly important in the present situation, where many of the problems facing science are complex, uncertainties are high, and decision-makers have to rely on advice from scientists. Therefore, an important objective of a course in philosophy of science for science students is to convey the importance of good judgement, wisdom and humility.
\end{abstract}

\section{Introduction}

If we go a few centuries back in time, to the scientific revolution of the seventeenth century, we will see that there was no strict division between science and philosophy. If we, for example read Galileo Galilei and René Descartes, we see that science and philosophy were two sides of the same coin. And Isaac Newton's major work on mechanics has the title Philosophice Naturalis Principia Mathematica ("Mathematical Principles of Natural Philosophy") (Newton 1971).

However, Newton was a member of the Royal Society (and later became its president), and the program of the society was to transform natural philosophy to experimental phi-

Ragnar Fjelland

ragnar.fjelland@uib.no

1 Centre for the Study of the Sciences and the Humanities, University of Bergen, Bergen,

Norway 
losophy. This is the beginning as what is normally regarded as the liberation of science from philosophy. Newton's contemporary John Locke declared himself an "under-laborer" in comparison to Newton (Locke 1971, 58, Burtt 1972, 18). He was followed by other philosophers, not least the logical positivists in the last century. For example, the prominent logical positivist Hans Reichenbach echoed Locke when he stated that the only thing "the philosopher can do is to analyze the results of science, to construe their meaning and stake out their validity." (Reichenbach 1949, 312).

However, Reichenbach underestimated the power of philosophy. It is almost ironical, because he had a close relationship to the most famous scientist of the last century, Albert Einstein (Canales 2017, 31). Einstein's special theory of relativity was directly inspired by the philosopher David Hume and the physicist, historian and philosopher of science Ernst Mach (Pais 1982, 133), and on several occasions Einstein emphasized the importance of history and philsophy of science. One example is an unpublished letter to Robert A. Thornton: "I fully agree with you about the significance and educational value of methodology as well as history and philosophy of science." (Quoted in Howard 2005, 34).

Therefore, the "liberation" of science from philosophy has not been an unambiguous process. However, after World War II, and after the landmark report of Vannevar Bush: Science, the Endless Frontier to the president of the United States in 1945, there has been a tremendous growth in science. This has been accompanied by an increasing specialization. Parts of science have developed into what the physicist Alvin Weinberg coined "Big Science". According to Weinberg huge rockets, high-energy accelerators and high-flux research reactors are as much a symbol of our time as Notre Dame is a symbol of the Middle Ages. (Weinberg 1961, 161)

Weinberg asked the question if Big Science may ruin science, and he discussed some of its negative effects. One of the them is that scientists may prefer to spend money rather than to think. Nevertheless he concluded that, "for better or for worse, it is here to stay" (Weinberg 1961, 162). However, the philosopher of science Karl Popper was more negative: "[T] oo many dollars may chase too few ideas" and "Big Science may destroy great science..." (Popper 1975, 96).

Weinberg was certainly right that Big Science has come to stay. It has not only come to stay, but has spread from physics and chemistry to large parts of science. Thomas Kuhn's charaterization of "normal science" as "puzzle-solving" gives an adequate description of Weinberg's Big Science.

Bush's emphasis on basic science complied with the traditional "social contract" between science and society. Only if science pursues its own goals, independently of society's expectations, it can produce the results that are the driving force in technological progress. However, the growth of science and its societal importance has changed this situation. Among others it is not longer possible to maintain a strict separation between basic science, applied science, and technology.

As a consequence, the "social contract" between science and society cannot be sustained. Science, and the institutions of science, cannot be completely autonomous, but have to be socially accountable. At the turn of the century the environmental scientist Jane Lubchenco called for a new social contract between science and society. She referred to Bush's report, and argued that the situation in the new century would be very different from the situation when he submitted his report. In the new century the overriding goal will be to promote a sustainable biosphere. 
Many of the challenges that face science today are complex, and require cooperation from scientists from different fields. The new situation requires a transdisciplinary approach. Transdisciplinarity is different from interdisciplinarity in the sense that the former, in addition to drawing on knowledge from various disciplines, requires the development of a new, common framework. In addition, the fact that science is present in all parts of society, and has consequences for our private lives, raises ethical problems that cannot be neglected or relegated to experts. In the influential book Rethinking Science: Knowledge and the Public in an Age of Uncertainty Helga Novotny and her co-authors summed up the new situation in the short sentence: "Society speaks back." (Novotny et al. 2001) The one-way communication will have to be replaced by a dialogue between science and society. (Gibbons 1999)

The impossibility of keeping up "business as usual" has implications for science education, because students represent the future of science. Although most scientists and students of science may not be convinced about the utility of philosophy, there is a growing demand for philosophy in science education. ${ }^{1}$ The initiative has for the most part come from outside the scientific community, for example the university administration and policy makers. In Norway courses in philosophy of science and ethics are today mandatory in most $\mathrm{PhD}$ programs.

However, this raises a problem that is addressed by Till Grüne-Yanoff in the article: "Teaching philosophy of science to Scientists: why, what and how." The author points out that most philosophers of science teach philosophy of science not to scientists, but to philosophers. He finds this unfortunate, because philosophers of science have something to contribute in science education. But this requires that some obstacles are overcome. One of the obstacles is that scientists and their students are skeptical of what philosophers can contribute. He admits that this skepticism is not without foundation, because "...not the entire standard philosophy of science curriculum is relevant for scientists." (Grüne-Yanoff 2014, 116).

Therefore, philosophers of science have not just to overcome the skepticism of scientists, but have to revise their own teacing program, the standard philosophy of science curriculum. (Grüne-Yanoff 2014, 117) I completely agree. However, although Grüne-Yanoff has some interesting suggestions for reform, he nevertheless maintains that the standard curriculum is hightly relevant for this kind of course in philosophy of science. I disagree. In this paper I will present an alternative curriculum, and give a description of the core topics.

First I will explain why scientists need philosophy. I will then present some of the theoretical justification of the alternative curriculum, and then I will give a more detailed description of five topics that make up the core of the alternative curriculum.

\section{Why Scientists Need Philosophy}

This paper is primarily about teaching philosophy of science to science students. As indicated in the introduction, I am afraid that the majority of scientists - and their studentswould agree with Nobel laureate in physics Steven Weinberg. In his book Dreams of a Final Theory there is a chapter with the title "Against Philosophy", where he argues that he knows no one who has contributed to the advance of physics in the postwar period who has been

\footnotetext{
${ }^{1}$ See, for example, the collection M.R. Mattews (ed.): History, Philosophy and Science Teaching. New perspectives (Mattews 2018) and Laplane et al.: "Why science needs philosophy" (Laplane et al. 2019).
} 
significantly helped by the work of philosophers. Alluding to the famous article by Eugene Wigner about "the unreasonable effectiveness of mathematics" he invents the expression "the unreasonable ineffectiveness of philosophy" (Weinberg 1993, 134). However, in his more recent book Facing Up he endorses parts of Thomas Kuhn's theory, although he criticizes him for not recognizing objective truth (Weinberg 2021, 85). Although Kuhn was more a historian than a philosopher of science, ironically enough, Weinberg might have included him in the chapter against philosophy. At the end of The Structure of Scientific Revolutions Kuhn describes how natural science students are socialized into a paradigm by reading textbooks, and he asks the question:

Why, after all, should the student of physics, for example, read the works of Newton, Faraday, Einstein, or Schrödinger, when everything he needs to know about these works is recapitulated in a far briefer, more precise, and more systematic form in a number of up-to-date textbooks? (Kuhn 1970, 165)

Then he adds:

Of course, it is a narrow and rigid education, probably more so than any other except perhaps in orthodox theology. But for normal-scientific work, for puzzle-solving within the tradition that the textbooks define, the scientist is almost perfectly equipped.

(Kuhn 1970, 166)

Although Kuhn's description of the development of science as a succession of periods of homogenous normal science, interrupted by scientific revolutions, is grossly simplified, it nevertheless contains some empirical truth. In particular, I think that many scientists will agree that their task as teachers is to socialize their students into the dominating paradigm of their own discipline.

Paul Feyerabend early criticized Kuhn for mixing up "is" and "ought", and for interpreting history according to the principle "ALLES WIRKLICHE IST VERNÜNFTIG" ("Everything real is rational", Hoyningen-Huene 1995, 355, capitals in original.). Karl Popper gave a similar comment on Kuhn's normal science. He did not doubt that it existed, but argued that it applied to "the not-too-critical professional: of the science student who accepts the ruling dogma of the day..." (Popper 1974, 52).

A narrow and rigid education may be efficient for some purposes, but it will develop "tunnel vision", it has little place for creativity and critical thinking, and it will not train students to cope with new situations, or to communicate across disciplinary borders. If we gave a description of civil society and the educational system similar to Kuhn's description of normal science education, most people would be alarmed, and argue that democracy is endangered. If we accept normal science as a norm, science itself is endangered.

I agree with Feyerabend and Popper that we have to prevent science from declining to Kuhn's "normal science". Courses in the history and philosophy of science are in themselves not a solution to the problem, but they may be part of the solution. However, some conditions must be satisfied for this to work. 


\section{Some Basic Assumptions}

The aim of a course in the history and philosophy of science should be to provide a deeper and broader understanding of a discipline, and of science more generally. "Deeper" here refers to basic assumptions, some of them formulated, and some of them tacit. Although many basic assumptions are taken for granted, they need not be "absolute" or "inevitable", and they may have limited validity. A simple example is significance tests. Students are told that a null-hypothesis should only be rejected if the probability that the result is obtained by chance is less than $5 \%\left(\mathrm{p}_{0}=0.05\right)$. I have sometimes asked an audience of $\mathrm{PhD}$ students of natural science if they know why the $5 \%$ limit is selected. In an audience of around fifty students I often do not get an answer. Once a student answered that it is selected because in a normal distribution two standard deviations make up $95 \%$. I asked why two standard deviations was selected, and got no answer. ${ }^{2}$ I will return to the question of significance tests later.

Grüne-Yanoff goes through nine textbooks in philosophy of science published in the period between 1999 and 2014, and makes a table of topics addressed. The table contains all of the traditional topics, like causation, demarcation, explanation, hypothesis testing, induction and confirmation, Popper, Kuhn etc. Although the topics look plausible enough, one should keep in mind a problem that the philosopher Luciano Floridi has pointed out: philosophical questions may become philosopher's questions. It may start with important questions that are interesting to everyone, but may develop into an "internal game" where the original problem is transformed to a technical question that has no relevance to the original problem. (Floridi 2017) Therefore, it is not only a question of the selection of topics, but the way they are treated. In many ttextbooks in the philosophy of science the topics mentioned above are treated in a way that has no relevance to real science.

"Broader" means that science is seen in a broader context, as part of society and as the result of a historical process, and, of course, it includes ethical questions. In the traditional philosophy of science approach it was by and large taken for granted that the natural sciences (in particular physics) cannot be changed, at least not in their structure. The task of the philosopher of science was to articulate the methods and rationality of science, and transfer them to less mature parts of science, and to other areas of human existence. Although this is the view still maintained by many philosophers of science, after the $1960 \mathrm{~s}$ an alternative development started.

Partly inspired by Kuhn, new branches developed in the study of science (science studies, science and technology studies, science and society etc.). Some of the more radical approaches can loosely be labelled "social constructivism" (or "social constructionism"). They all have in common their challenge of what might be called "the inevitability thesis", which is still widely held in the scientific community. The advocates of this view argue that the basic aim of science is the pursuit of truth, and therefore, the only norms and values that are compatible with this aim are the internal norms of science itself. Any attempt to implement other norms will be detrimental to science. Stephen Weinberg, put it this way:

To put it another way, if we ever discover intelligent creatures on some distant planet and translate their scientific works, we will find that we and they have discovered the same laws. (Weinberg 1996)

\footnotetext{
${ }^{2}$ For the history of significance tests, see for example (Ziliak and McCloskey 2014).
} 
A similar view has been advocated by philosophers, for example Susan Haack (1993 and 1998) and Philip Kitcher (2001).

Some social constructivists, including feminist science critics, have even challenged the ideal of scientific objectivity and neutrality. The critics have argued that far from being value neutral, the ideal of science represents prevalent masculine values: abstract, detached etc. It is sometimes explicitly said - and often tacitly assumed - that alternatives are possible. (For some typical examples, see Keller 1985, 2002, Shapin and Schaffer 1985, Latour and Woolgar 1986, Collins and Pinch 1993, Anderson 1995, Longino 1994, Stengers 2017.)

Although these contributions are valuable in preventing "scientism" and "scientific fundamentalism", and may contribute to a deeper and broader understanding of science, I will not include them among the central core topics of a course in philosophy of science.

The guiding principle behind all teaching must be that what is taught must be, and must be perceived as, relevant for the students. A good strategy is to start with problems that are addressed inside the sciences by the scientists themselves, and preferably use texts written by scientists interested in philosophical questions. Philosophers have a place, but they must have one foot inside the discipline they are dealing with. She or he should be what Feyerabend called "a universal dilettante who tries to see things in perspective" (Feyerabend 1991, 153).

For some reason Grüne-Yanoff has left out the book that is closest to what I have in mind, Ronald Giere: Understanding Scientific Reasoning (Giere 1997) ${ }^{3}$ This is a widely used introductory text at the undergraduate level. The book is supposed to give the basics of scientific reasoning and to evaluate scientific information in a more critical way. The virtue of the book is that it is closer to real science than many other introductory textbooks in philosophy of science. For example, it deals with models, statistics, including randomized, prospective and retrospective trials, the notion of cause as used in epidemiology, and theory of decision making. The reader is supposed to learn, for example, what it means that smoking causes cancer. It has many good examples from real-life science. The weakness of the book is, however, that it by and large contains prescriptions, and hardly any philosophical discussions ${ }^{4}$.

However, the book's main flaw is shared with other textbooks. Sources of error, ignorance and irrationality are placed outside science. The book has a chapter with the title "Marginal science". In this chapter psychoanalysis, astrology, extraterrestrial visitation, reincarnation and extrasensory perception are dealt with. There is nothing wrong with this. But it is a striking fact that the book does not address the problem of errors within science, or the abuse of science. If the aim of the book is to promote a scientific attitude, this is a serious omission. It is not very probable that students of science would believe in astrology, and it is even less probable that they will abuse it in their scientific activity. There is a much higher chance that they may be victims of "tunnel vision", and abuse their own discipline in contexts where it is not applicable. There are numerous examples of scientists and experts abusing their own expertise, either out of ignorance of the limits of their competence, or lack of ethical considerations ${ }^{5}$. Needless to say, this approach should not be mistaken for anti-

\footnotetext{
${ }^{3}$ The book has been published in five editions. I refer to the 4. edition. The 5. edition is Ronald Giere: Understanding Scientific Reasoning, Belmont, Calif.: Wadsworth 2004.

${ }^{4}$ However, Giere discusses the theoretical foundation of the book in (Giere 2001).

${ }^{5}$ I have given some examples in (Fjelland 2002 and 2016).
} 
science. Knowledge of the limits of scientific knowledge is an important part of scientific knowledge, and a basic scientific virtue.

The central core of the alternative curriculum that I propose consists of five topics: (1) Why is science so important in modern society? (2) measurements and mathematics, (3) statistics, (4) reductionism and (5) the pursuit of certainty. This list contains the core topics, but the list is not complete. For example, the uses and abuses of models may be a separate topic, and topics on ethics should be included as well. A topic labeled "classics in philosophy of science", on Popper, Kuhn and Feyerabend is also in place.

The five topics that make up the core of the course follow from the insight that science has been, and still is, dominated by a scientific ideal that goes back to the scientific revolution of the seventeenth century. In this ideal measurements and mathematics play a key role. To understand what this means I agree with Feyerabend that a historical approach is superior to a logical approach:

Yes, I learned a lot from Kuhn. It was he (and Carl Friedrich von Weizsaecker) who convinced me that you have to approach science, the arts etc. etc. historically, by retracing their life stories, and not logically, i.e. by trying to capture some permanent structures. (Feyerabend 1991, 156)

Although these topics are particularly relevant for natural science students, some, or all of them, are relevant for social science, psychology and medicine as well.

I will now go through the five topics.

\section{Science: The Endless Frontier}

Why do we have science? The traditional answer was already given by Aristotle, in the very first sentence of his Metaphysics: "All men by nature desire to know." (Aristotle 1984a, 980a25) Knowledge as an end in itself is still used as a powerful justification for science. However, if it had been the only justification, society would hardly have invested the enormous resources in science as we see today. In particular after World War II there has been a massive increase in the resources allocated to scientific research.

A better explanation for this fact can be found in Vannevar Bush's report that I referred to in the introduction. The summary of the report contains the following:

Progress in the war against disease depends upon a flow of new scientific knowledge. New products, new industries, and more jobs require continuous additions to knowledge of the laws of nature, and the application of that knowledge to practical purposes. Similarly, our defense against aggression demands new knowledge so that we can develop new and improved weapons. This essential, new knowledge can be obtained only through basic scientific research. (Bush 1960, 5)

Bush was basically an engineer. As director of the Office of Scientific Research and Development he had been the head of all military research in the United States during World War II. It is, therefore, amazing that in the report he emphasized the importance of basic science.

Bush's report has been highly influential, not only for science policy in USA, but worldwide as well. It can be placed in the tradition from the founding fathers of modern science. The idea that science is a means to controlling nature was already formulated by Francis Bacon and René Descartes. In Discourse on Method Descartes argued that knowledge of 
"... the power and the effects of fire, water, air, the stars, the heavens and all the other beings which surround us" can make us "... the masters and possessors of nature." (Descartes 1968, Sixth Discourse).

Although Bacon and Descartes dreamt of mastering nature, for centuries it remained a dream. With a few exceptions it was not until World War II that this dream could be realized, and the program for the new era is formulated in Bush's report. Basic science reveals the laws of nature, and this knowledge can then be transformed to applied science. Applied science can then be implemented in technological innovations, creating new products, new jobs and improved social welfare. This is known as the "linear model"'.

There is no doubt that Big Science has been efficient. However, it has not been as efficient as we tend to think. In 1996 Daniel Sarewitz published the book Frontiers of Illusion. The title alludes to Vannevar Bush's report, and it compares the visions of the report with what has actually been accomplished. The conclusion is rather gloomy: While the funding of "research and development has been justified by its promised contribution to human walfare, the fulfillment of this promise seems increasingly elusive." (Sarewitz 1996, 3).

\section{Measurements and Mathematics}

It is a widely accepted view that science is characterized by a scientific method. Traditionally historians and philosophers of science thought that it was based on observation and experiments. However, thanks to the historians of science Edmund Burtt (Burtt 1972) and Alexandre Koyré (Koyré 1978), and later Thomas Kuhn, this view has changed. Although observation and experiment are important, modern science is first and foremost characterized by the importance of measurements and mathematics.

Therefore, physics has not only been regarded as the most advanced science, but as the model that all sciences were supposed to imitate. (Cohen 1994, 101) It was no accident that when the US Congress in 1950 decided to establish a National Science Foundation, as had been proposed in Vannevar Bush's report, only the natural sciences were allowed to take part. The social sciences and the humanities were not allowed because they were regarded as "soft" sciences, in contrast to the "hard" natural sciences. (Cohen 1994, 154)

An example of this attitude is the quotation from William Thompson (Lord Kelvin) inscribed on the façade of the Social Science Research Building at the University of Chicago: "If you cannot measure, your knowledge is meager and unsatisfactory." (Kuhn 1977, 178).

A formal treatment of measurements (for example different kinds of scales) may be useful, but a historical approach teaches us that the magnitudes that are measured, are normally not pre-given "out there", ready to be measured. For something to be measured, simplification, idealization and standardization is required. A historical example is a good illustration: In eighteenth century Europe grain was traded in the local unit of a bushel (approx. 35 1). The price was always a combination of quality and quantity. However, the introduction of universal units (metric system) required a standardization of the quality of the grain. (Porter 1995, 24)

In addition I want to mention one method that follows from the mathematical approach: the analytic method. It consists in isolating a phenomenon, decomposing it into elements, and then recomposing it again. Galilei called it "metodo risolitivo" and "metodo composi-

${ }^{6}$ On Bush's report and the linear model, see (Stokes 1997, chapt. 1). 
tivo", and he used it in his treatise on motion. However, the best example of the method is Isaac Newton's "crucial experiment", where he first decomposed white light into the spectral colors and then recomposed them to white light. (Newton 1952, 186-91)

Newton also pointed out that light with different refrangibility (today we would say different wavelengths) can be combined to colors that do not exist in nature. This is the most important method for developing technology: We decompose phenomena, and then put them back together in combinations that do not exist in nature. It is precisely this method that chemists use when synthesizing chemical substances. Science and technology thus become a means of controlling nature.

However, equally important as knowing when to introduce measurements is to know when measurements should not be introduced. A paradigmatic example of the systematic abuse of measurements was given by Robert McNamara. He was Secretary of Defense in the Kennedy administration during the Vietnam war, and later became the president of the World Bank. He had a fundamental trust in measurements and numbers. Among others he introduced a mathematical measure of the progress of the war in Vietnam (body counts, the number of killed enemies), and he failed spectacularly.

The sociologist Daniel Yankelovitch coined the term the "McNamara fallacy":

The first step is to measure whatever can be easily measured. This is OK as far as it goes.

The second step is to disregard that which can't be easily measured or to give it an arbitrary quantitative value. This is artificial and misleading.

The third step is to presume that what can't be measured easily really isn't important.

This is blindness.

The fourth step is to say that what can't be easily measured really doesn't exist. This is suicide. (O’Mahony 2017, 281) ${ }^{7}$

There are numerous examples of the "McNamara fallacy" in Muller (2018) and Pilkey and Pilkey-Jarvis (2007).

\section{Statistics}

Newton's mechanics is deterministic. When we know the initial state of the system, we can in principle predict future states with infinite accuracy. However, it was early recognized that not all sciences would be able to live up to this ideal. It is therefore no accident that mathematical theories of probability and statistics were developed just after the scientific revolution. During the nineteenth century social statistics was used as an important part of the modern project. One of the pioneers in the application of statistics to social phenomena was Adolphe Quetelet. He was the royal astronomer of Belgium, and believed that just as the celestial bodies follow laws, there are laws for human behavior as well. (Hacking 1991, 105) He started with the chest width and height of soldiers, and found that they are normally distributed. He transferred this to social phenomena, and it has been said that he had green fingers for finding normal distributions. He called this subject "social physics". This term

\footnotetext{
${ }^{7}$ The original reference is Daniel Yankelovich, Corporate Priorities: A continuing study of the new demands on business, Stanford, CT: Yankelovich Inc, 1972. It looks as if the article only exists in paper version, deeply buried in the archives of Stanford University. I have not been able to retrieve a copy.
} 
had actually been introduced by August Comte, but when Comte discovered that Quetelet had taken over the term, he introduced the term "sociology" instead.

During the twentieth century statistical methods became an integral part of many empirical sciences. For example, randomized trials and significance tests became a standard method in medicine. The paradigmatic use of randomized trials is the testing of drugs: A group is given the drug to be tested, and another group is given no drug or a placebo. The two groups are supposed to be identical, except for the drug. The question is then: Is there a difference between the two groups, and is this difference real, and not just due to random variations? A standard method assumes as a hypothesis (the null hypothesis) that the difference is due to random variations, and it is only rejected if the probability that it is not due to random variations is below a certain level (the significance level, $\mathrm{p}_{0}$ ). In that case the difference is significant. However, two errors are possible: Type 1 error: The null hypothesis is erroneously rejected. There was no difference, but we believe that there is ("false positive"). Type 2 error: We fail to reject the null hypothesis even if there is a real difference ("false negative").

In 2005 the epidemiologist John P. A. Ioannidis published the article "Why Most Published Research Findings Are False" (Ioannidis 2005). Using simple examples of type 1 and type 2 statistical errors he showed, as the title of the paper says, that most published research findings are false. This initiated a debate among statisticians, and in 2014 the American Statistical Association issued a statement where they warned against the uncritical use of significance tests. The introduction of the article offers a good illustration of the detrimental effect of Kuhn's normal science. It goes like this:

Q: Why do so many colleges and grad schools teach $\mathrm{p}=0.05$ ?

A: Because that's still what the scientific community and journal editors use.

Q: Why do so many people still use $\mathrm{p}=0.05$ ?

A: Because that's what they were taught in college or grad school. (Wasserstein and Lazar 2016, 129)

It is important to keep in mind that significance tests only concerns random errors, due to chance. In most situations systematic errors are much more important: Experimental errors, measurements errors, sampling bias, wrong models etc. I return to the problem of uncertainty later.

\section{Reductionism}

It is an old idea, already found in Aristotle, that all things can be ordered in a kind of hierarchy according to their complexity. The hierarchy can for example be ordered according to the categories whole/part, as organisms, cells, molecules, atoms, elementary particles, quarks etc. What is whole at one level, consists of the parts at the lower level. The question is then: Can one level be reduced to a lower level? The crucial question is what is meant by "reduced". To study something we normally have to go from the whole to the part. "Methodological reductionism" is not controversial. However, if we argue that the whole is "nothing but" the parts, we have what is sometimes called "ontological reductionism". In the following I will just use "reductionism".

If we look at the history of science from the scientific revolution until today, it has by and large been reductionist. Organisms consist of cells, cells of molecules and molecules 
of atoms. We may then argue that, in the end, everything is "nothing but atoms". The codiscoverer of the structure of DNA, James Watson, once said: "There is only one science, physics: all the rest is social work." (Rose 1998, 8) ${ }^{8}$

There are two fundamental assumptions behind this, and they both go back to Galileo and Descartes: The assumption that there is one reality "at the bottom", and that we acquire access to this reality by applying an analytic method. However, these two assumptions cannot be taken for granted. Some anti-reductionists argue that complex systems cannot generally be taken apart without something being lost. This view is expressed in the slogan that the whole is more than the sum of the parts. It is also called "holism". The most used term today is emergence: Properties emerge at one level, and cannot be reduced to a lower level.

Ludwig von Bertalanffy has given a more precise definition of the condition that the whole is more than the sum of the parts. He pointed out that the application of the analytic method requires that two conditions be satisfied: The first is that the interactions between the parts of the system are weak. The second is that the equations describing the behavior of the parts are linear. If these two conditions are not satisfied, the analytic method cannot be applied. (Bertalanffy 1973, 16-17) von Bertalanffy was originally a biologist, and later became one of the founders of general systems theory.

It is worth noticing that even physicists may be anti-reductionists. In 1972 the journal Science published an article by the physicist Philip Anderson with the title "More is Different". The article is amazing, not primarily because it argued in favor of anti-reductionism in general, but because it argued for anti-reductionism within physics itself.

For the most part Anderson restricted himself to physics. His main point was that even inanimate matter has properties at higher levels that cannot be reduced to lower levels. For example, properties of gold metal have only meaning at a macroscopic level, because a simple atom of gold cannot be yellow and shiny and conduct electricity. He concluded that "... the whole becomes not only more than but very different from the sum of its parts" (Anderson 1972, 395).

Anderson started by pointing out that with the possible exception of some philosophers, the overwhelming majority of scientists are reductionists. However, his general conclusion was:

At each stage entirely new laws, concepts, and generalizations are necessary, requiring inspiration and creativity to just as great a degree as in the previous one. Psychology is not applied biology, nor is biology applied chemistry. (Anderson 1972, 393)

The strongest anti-reductionist argument is that there is not one single reality "at the bottom". In a complex system, each level has its distinct, emergent, properties that are characteristic of this level. Therefore a complex system should be investigated at different levels and from different perspectives. (See, for example Auyang 1998, 16)

\section{The Pursuit of Certainty}

Already Galileo knew that to investigate a phenomenon, we have to simplify and idealize. The results of our investigations are therefore not unconditionally valid in the natural world.

\footnotetext{
${ }^{8}$ Watson said this in a debate with Rose at the Cheltenham Book Conference in 1994.

${ }^{9}$ This is the kind of article a scientist would normally write after he has won a Nobel Prize. However, Anderson won the Nobel Prize for physics five years later, in 1977.
} 
He pointed for example out that his law of freely falling bodies was only valid in the ideal case of no friction. (Galilei 1954, 72) However, it has traditionally been assumed that what has been left out, for example friction, can later be "added back" to give a more adequate description of real phenomena.

This works for simple systems, and the calculation of planetary orbits by adding more planets to the calculations is the success story. However, the world is complex, and this does not in general work for complex systems. Ecologists know this. One may study a simplified version of an ecosystem in the laboratory, but factors that play no role in the natural system, may have a large influence in the laboratory system, whereas factors that play no role in the laboratory system, are decisive in the natural system. In other words, there is a non-linear relationship between phenomena in the laboratory and in natural systems. (Peters 1991, 138)

One consequence is that in complex systems uncertainty cannot always be reduced or eliminated. Therefore, scientists and technologists have in many ways come into a new situation. Environmental problems, in particular global warming, are typical examples. These encompass totally different problems than scientists and technologists are traditionally trained to deal with. (Funtowicz and Ravetz 1991, 85 and 1993)

The problem can be formulated in the language of risk assessment. One normally distinguishes between three different cases: (1) Risk: We know the possible outcomes, and we know the probabilities. (2) Uncertainty: We know the possible outcomes, but we do not know the probabilities ("known unknowns"). (3) Ignorance: We neither know the outcomes nor the probabilities ("unknown unknowns"). The problem is that when we want to make risk calculations, we introduce simplified models. Then we have numbers. However, the cost may be increased ignorance.

This does not only apply to nature, but to our social world as well. An illustrative example is given by Nassim Taleb in The Black Swan. He was once invited to a seminar on probability theory. The seminar had been located to the biggest casino in Las Vegas. Casinos have sophisticated models to handle risk: Gambling policy (based on the laws of probability, in the long run they will always win), they diversify their activity to avoid being bankrupted by an extremely lucky gambler and they take many precautions to detect cheaters. However, before the seminar started, Taleb made some inquiries about previous losses of the casino. He learned that the casino had lost money on four occasions:

1. It lost $\$ 100$ million when an irreplaceable performer in their main show was maimed by a tiger.

2. A dissatisfied contractor tried to blow up the casino.

3. An employer had for years not sent in the tax forms. The casino had to pay large amounts in fines, and almost lost its license.

4. The casino owner's daughter was kidnapped, costing a huge sum in ransom.

Taleb concludes:

A back-of-the-envelope calculation shows that the dollar value of these Black Swans, the off-model hits and potential hits I've just outlined, swamp the on-model risks by a factor of close to 1000 to 1 . The casino spent hundreds of millions of dollars on gambling theory and high-tech surveillance while the bulk of their risks came from outside their models. (Taleb 2008, 130) 


\section{Conclusion: From the Endless Frontier to the Finite Earth}

As mentioned in the introduction, Jane Lubchenco argued that science today is in a new situation:

The current and growing extent of human dominance of the planet will require new kinds of knowledge and applications from science - knowledge to reduce the rate at which we alter the Earth systems, knowledge to understand Earth's ecosystems and how they interact with the numerous components of human-caused global change, and knowledge to manage the planet. (Lubchenco 1998, 495)

Lubchenco called for a new social contract between science and society, where the overriding goal is to promote a sustainable biosphere. According to this new contract scientists shall "exercise good judgement, wisdom and humility".

One of the main objectives of a course in philosophy of science is to remind the students of the fact that science is in a situation that is very different from the situation when Vannevar Bush's report was submitted. In the old social contract it was possible to disregard ethical and societal problems. Because many scientists worked on problems that were regarded as basic science, they could leave ethical problems to people working on applied science and technology. In the new situation it is impossible to keep up a strict division between basic science, applied science and technology.

Therefore, as the physicist and sociologist of science John Ziman put it:

Even the "purest", "most basic" research is thus endowed with potential human consequences, so that researchers are bound to ask themselves whether all the goals of the activity in which they are engaged are consistent with their other personal values. (Ziman 1998, 1814)

I will use Lubchenco's key-words "good judgement", "wisdom" and "humility" to conclude this paper.

First: good judgement. I have previously mentioned Robert McNamara, who gave name to "the McNamara fallacy". He instituted a "numbers-only mentality" in all the institutions he lead, from Ford Motor Company to the World Bank. He was a very intelligent, highly educated person with a scientific attitude, but he obviously lacked both good judgement, wisdom and humility.

McNamara should have learned the following:

There are things that can be measured. There are things that are worth measuring. But what can be measured is not always what is worth measuring: what gets measured may have no relationship to what we really want to know. (Muller 2018, 3)

To find out what is worth measuring, in contrast to what can be measured, needs good judgement. Aristotle already knew this. He pointed out that the young may be experts in geometry and mathematics and similar branches of knowledge, but they lack good judgement, prudence: The reason is that prudence (phronesis) requires knowledge of particular facts, and can only be acquired from experience. (Aristotle 1884b, 1142a) A course in philosophy of science cannot replace experience, but the uses of cases may guide the student in the right direction. 
Second: wisdom. Wisdom entails the ability to put things into a larger context, and have a grip on the whole. This is what Aristotle called "philosophical wisdom", which is the supreme virtue (Aristotle 1884b, 1140b30). I will not go into a lengthy discussion of the concept, but restrict myself to dealing with the question: What would the wise man have done if he had been in McNamara's shoes as secretary of defense during the Vietnam war? He need not have asked the ultimate philosophical questions, but he might have started with asking why the Americans were in Vietnam, and continued with the question if they had the moral right to be there. He might go further, and ask under what conditions we have the right to kill, in particular civilians. The wise man might even have ended up with a philosophy of non-violence, like Mahatma Gandhi.

Third: humility. We may ask the question why Socrates was a wise man, and McNamara was not. One difference is that Socrates was able to ask fundamental questions, whereas McNamara was not. However, the main difference between Socrates and McNamara was that Socrates was aware of his own ignorance, of the limits of his own knowledge, whereas McNamara was not. The distinguishing mark of Socrates was his humility. Karl Popper refers to Socrates as the primary representative of Popper's "true rationalism":

It is the awareness of one's limitations, the intellectual modesty of those who know how often they err, and how much they depend on others even for this knowledge. (Popper 1966 vol 2, 227)

I have argued that science is in a new situation. However, this remains the supreme scientific virtue. If a course in philosophy of science is able to convey this attitude, it is definitely not a waste of time.

Acknowledgements I want to thank Roger Strand, who has given valuable contributions to the course. I also want to thank two anonymous reviewers for this journal who have offered valuable suggestions for improvement.

Funding Open access funding provided by University of Bergen (incl Haukeland University Hospital).

Open Access This article is licensed under a Creative Commons Attribution 4.0 International License, which permits use, sharing, adaptation, distribution and reproduction in any medium or format, as long as you give appropriate credit to the original author(s) and the source, provide a link to the Creative Commons licence, and indicate if changes were made. The images or other third party material in this article are included in the article's Creative Commons licence, unless indicated otherwise in a credit line to the material. If material is not included in the article's Creative Commons licence and your intended use is not permitted by statutory regulation or exceeds the permitted use, you will need to obtain permission directly from the copyright holder. To view a copy of this licence, visit http://creativecommons.org/licenses/by/4.0/.

\section{References}

Anderson, Elizabeth. 1995. Knowledge, Human Interests, and Objectivity in Feminist Epistemology. Philosophical Topics 2/1995: 27-57.

Anderson, P. W. 1972. More Is Different. Science 177 (4047): 393-396.

Aristotle. 1984a. "Metaphysics (Transl. By W. D. Ross)." In The Complete Works of Aristotle, edited by Jonathan Barnes. Vol. 2. Bollinger Series Lxxi.2. Princeton: Princeton University Press.

Aristotle. 1984b. "Nichomachean Ethics (Transl. W. D. Ross, Revised by J. O. Urmson)." In The Complete Works of Aristotle, edited by Jonathan Barnes. Vol. 2. Bollinger Series Lxxi.2. Princeton: Princeton University Press. 
Auyang, Sunny Y. 1998. Foundations of Complex-System Theories. Cambridge: Cambridge University Press. Bertalanffy, Ludwig von. 1973. General System Theory. Harmondsworth: Penguin Books.

Burtt, Edwin Arthur. 1972. The Metaphysical Foundations of Modern Physical Science (1924). London: Routledge and Kegan Paul.

Bush, Vannevar. 1960. Science - the Endless Frontier (1945). Reprinted. Washington D.C.: National Science Foundation.

Canales, Jimena. 2017. The Physicist and the Philosopher. Princeton: Princeton University Press.

Cohen, I. Bernard. 1994. Interactions: Some Contacts Between the Natural Sciences and the Social Sciences. Cambridge, Mass. and London: The MIT Press.

Collins, Harry, and Trevor Pinch. 1993. The Golen: What everyone should know about science. Cambridge: Cambridge University Press.

Descartes, René. 1968. "Discourse on Method.". In Discourse on Method and the Meditations (1637), Trans. by S. E. Sutcliffe. Harmondsworth: Penguin Books.

Feyerabend, Paul. 1991. Three Dialogues on Knowledge. Oxford: Basil Blackwell.

Fjelland, Ragnar. 2002. Facing the Problem of Uncertainty. Journal of Agricultural and Environmental Ethics 15: 155-169.

Fjelland, Ragnar. 2016. "When Laypeople Are Right and Experts Are Wrong: Lessons from Love Canal." HYLE-International Journal for Philosophy of Chemistry 22: 105-25.

Floridi, Luciano. 2017. "Why Information Matters". The New Atlantis, no. 51: 7-16. https:/www.thenewatlantis.com/publications/why-information-matters. (accessed 24.8.2021).

Funtowicz, Silvio, and Jerome Ravetz. 1991. “The Emergence of Post-Normal Science.” In Ecological Physical Chemistry, Proceeding of an International Workshop, edited by C. Rossi and E. Tiezzi. Amsterdam: Elsevier Science Publishers.

Funtowicz, Silvio, and Jerome Ravetz. 1993. "Science for the Post-Normal Age", Futures, September: $739-755$.

Galilei, Galileo. 1954. Dialogues Concerning Two New Sciences (1638). New York: Dover.

Gibbons, M., C. Limoges, H. Novotny, S. Schwartzman, P. Scott, and M. Trow. 1994. The new production of knowledge. London: Sage Publications.

Gibbons, M. 1999. "Science's new social contract with society", Nature 402/Supp/2 December, C81-84.

Giere, Ronald. 1997. Understanding Scientific Reasoning. 4th ed. Fort Worth: Harcourt Brace Jovanovich College Publishers.

Giere, Ronald N. 2001. A New Framework for Teaching Scientific Reasoning. Argumentation 15: 21-33.

Grüne-Yanoff, Till. 2014. Teaching Philosophy of Science to Scientists: Why, What and How. European Journal for the Philosophy of Science no. 4: 115-134.

Haack, Susan. 1993. Evidence and Inquiry. Towards Reconstruction in Epistemology. Malden, Massachusetts: Blackwell.

Haack, Susan. 1998. Manifesto of a Passionate Moderate. Unfashionable Essays. Chicago: The University of Chicago Press.

Hacking, Ian. 1991. The Taming of Chance. Cambridge: Cambridge University Press.

Hoyningen-Huene, Paul. 1995. Two Letters of Paul Feyerabend to Thomas S. Kuhn on a Draft of the Structure of Scientific Revolutions. Studies in the History and Philosophy of Science 26 (3): 353-387.

Howard, Don A. 2005. "Albert Einstein as a Philosopher of Science”. Physics Today December 2005: 34-40.

Ioannidis, John. 2005. Why Most Published Research Findings Are False. PloSMedicine 2 (8): 696-701.

Keller, Evelyn F. 1985. Reflections on Gender and Science. New Haven: Yale University Press.

Keller, Evelyn F. 2002. Making Sense of Life. Cambridge, Mass.: Harvard University Press.

Kitcher, Philip. 2001. Science, Truth, and Democracy. New York: Oxford University Press.

Koyré, Alexandre. 1978. Galileo Studies (1939). London: Harvester.

Kuhn, Thomas. 1970. The Structure of Scientific Revolutions. Second Edition. Chicago: The University of Chicago Press.

Kuhn, Thomas. 1977. "The Function of Measurement in Modern Physical Science." In The Essential Tension, 178-224. University of Chicago Press.

Laplane, Lucie, Paolo Mantovani, Ralph Adolphs, Hasok Chang, Alberto Mantovani, and Margaret McFall Ngai. 2019. Carlo Rovelli, Elliott Sober and Thoas Pradeu. "Why science needs philosophy”, PNAS, March 5 116 (10): 3948-3952.

Locke, John. 1971. An Essay Concerning Human Understanding (1690). Edited by A. D. Woozley. London and Glasgow: Fontana/Collins.

Longino, Helen. 1994. "In Search of Feminist Epistemology", Monist 77/472-485.

Latour, Bruno, and Steve Woolgar. 1986. Laboratory Life. Princeton: Princeton University Press.

Lubchenco, Jane. 1998. "Entering the Century of the Environment: A New Social Contract for Science." Science 279, 23. January, 491-497. 
Mattews, Michael R., ed. 2018. History, Philosophy and Science Teaching. New Perspectives. Edited by Kostas Kampourakis. Science: Philosophy, History and Education. Springer.

Muller, Jerry Z. 2018. The Tyranny of Metrics. Princeton University Press.

Newton, Isaac. 1952. Opticks, or a treatise of the reflections, refractions, inflections and colours of light (fourth ed. London 1730). 4th ed. New York: Dover.

Newton, Isaac. 1971 Principia (1687). Berkeley, Los Angeles, London: University of California Press.

Novotny, H., P. Scott, and M. Gibbons. 2001. Re-thinking Science: Knowledge and the Public in an Age of Uncertainty. Cambridge: Polity Press.

O'Mahony, S. 2017. Medicine and the McNamara Fallacy. Journal of the Royal College of Physicians of Edinburgh 47 (3): 281-287.

Pais, Abraham. 1982. 'Subtle Is the Lord...' the Science and the Life of Albert Einstein. Oxford: Oxford University Press.

Peters, Robert. 1991. A Critique for Ecology. Cambridge: Cambridge University Press.

Pilkey, Orrin H., and Linda Pilkey-Jarvis. 2007. Useless Arithmetic. New York: Columbia University Press. Popper, Karl R. 1966. The Open Society and Its Enemies. 5th ed. Routledge; Kegan Paul.

Popper, Karl R. 1974. "Normal Science and Its Dangers." In Criticism and the Growth of Knowledge, edited by Imre Lakatos and Alan Musgrave, 51-58. London: Cambridge University Press.

Popper, Karl R. 1975. “The Rationality of Scientific Revolutions.” In Problems of Scientific Revolutions, edited by Rom Harré. Oxford University Press.

Porter, Theodore M. 1995. Trust in Numbers. Princeton University Press.

Reichenbach, Hans. 1949. "The Philosophical Significance of the Theory of Relativity." In Albert Einstein: Philosopher-Scientist, edited by Paul Arthur Schilpp, 1:287-312. La Salle, Illinois: Open Court.

Rose, Steven. 1998. Lifelines. Biology Beyond Determinism. Oxford: Oxford University Press.

Sarewitz, Daniel. 1996. Frontiers of Illusion. Philadelphia: Temple University Press.

Shapin, Steven, and Simon Schaffer. 1985. Leviathan and the Air-Pump. Princeton: Princeton University Press.

Stokes, Donald E. 1997. Pasteur's Quadrant. Brookings Institution Press.

Stengers, Isabelle. 2017. Another Science is Possible. Cambridge: Polity Press.

Taleb, Nassim Nicholas. 2008. The Black Swan. London: Penguin Books.

Wasserstein, Ronald L., and Nicole A. Lazar. 2016. The ASA's Statement on P-Values: Context, Process, and Purpose. The American Statistician 70 (2): 129-133.

Weinberg, Alvin M. 1961. Impact of Large-Scale Science on the United States. Science 134 (3473): 161-164.

Weinberg, Steven. 1993. Dreams of a Final Theory. London: Hutchington Radius.

Weinberg. 1996. "Sokal's Hoax", The New York Review of Books, Vol XLIII, No. 13: 11-15, Aug. 8.

Weinberg. 2001. Facing up. Science and Its Cultural Adversaries. Cambridge, Mass.: Harvard University Press.

Ziliak, Stephen T., and N. Deirdre, and McCloskey. 2014. The Cult of Statistical Significance. Ann Arbor: The University of Michigan Press.

Ziman, John. 1998. Why Must Scientists Become More Ethically Sensitive Than They Used to Be? Science 282 (5395): 1813-1814.

Publisher's Note Springer Nature remains neutral with regard to jurisdictional claims in published maps and institutional affiliations. 